\title{
Perspective of Competitive Advantage in Services Dominant Logic
}

\author{
Surya Bintarti ${ }^{1}$, Ali Nur Ahmad ${ }^{2}$, Agustini Tanjung ${ }^{3}$, Ergo Nurpatria Kurniawan ${ }^{4}$ \\ 1,2,3Pelita Bangsa University, Indonesia \\ ${ }^{4}$ STIE IPWIJA, Indonesia \\ \{surya.bintarti@pelitabangsa.ac.id', ali.ahmad@pelitabangsa.ac.id², \\ agustini.tanjung@pelitabangsa.ac.id ${ }^{3},{ }^{4}$ ergonurpatria@stieipwija.ac.id $\left.{ }^{4}\right\}$
}

\begin{abstract}
The process of marketing activities is the process of transactions occurring between producers and consumers, where producers market to consumers. The development of a globally connected world environment has resulted in a level of competition between companies not only on a domestic scale but also becoming global. The competition requires different perspectives both theoretically and practically to be able to provide the best for consumers so that companies can continue to exist in the long run and are not easily imitated by competitors or have competitive advantage. Marketing as an economic exchange model initially had a dominant logic based on the exchange of products or known as Goods-Dominant logic. Good- Dominant Logic focuses on the separation between producers and consumers and this is still used. It aims to maximize production control, efficiency, and profit maximization. This is usually achieved by standardizing products and producing them far from the market. Vargo and Lusch (2004) introduce a new dominant logic that is different from the goods-dominant logic. Dominant-logic focuses on the interaction between producers, consumers, and partners in the bidding network and the creation of value as parties who co-create through the process of collaboration. This logic is known as Service-Dominant logic. ServiceDominant logic arises because of the impetus of the initial goal to do something for and with other parties better known as customer centric and customer responsive. In this logic, services are defined as the application of competencies through actions, processes and performance that are beneficial to other entities and the entities themselves. This can increase the company's strength to satisfy consumer needs and achieve organizational and social goals. In this case the company can be said to have the power to compete through services. And competition through services is more than adding value to the product. Effective competition through services must be carried out with the views and approaches of all parties in the organization aimed at providing satisfaction to consumers (Lusch et al., 2007). In short, it can be said that service-dominant logic becomes the philosophical foundation for service science and service systems as the basis of theoretical constructs (Maglio and Spohrer, 2007). This research explains the new dominant logic, how changes in perspective occur, and how new can become conceptual based on the service science that producers try to provide or offer to consumers, and this becomes a competitive force and implications for business.
\end{abstract}

Keywords: Dominant Logic, Services, Service Competition

\section{Introduction}

COVID-19 conditions that hit the world (Rothan and Byvydy 2020) and the beloved country of the Republic of Indonesia had an impact on economic development in each country. The 
economy stopped for a moment due to various government policies with restrictions on various activities that are currently and will be carried out, all done in order to maintain and overcome the COVID-19 disaster. One of the conditions for limiting these activities is that businesspeople must think hard, how to keep their production operations running, and in accordance with the government's recommendation in June 2020, all forms of activities can run as they should with the conditions that they must carry out procedures set by the government is by implementing good and correct health protocol standards. This government policy brought a very heavy transition for many people, especially business people. The current condition requires business people, especially UKMK businesses not only to think about how to sell goods to consumers without having to think how to sell goods to consumers with maximum service so that consumers can be more satisfied or can be served well.

The description of current events increasingly proves that the theory of dominant logic (Harrington et al. 2019) which is based on the exchange of products or known as GoodsDominant logic (Lusch, Vargo, and O'Brien 2007). Good-Dominant Logic which only focuses on the separation between producers and consumers is rejected by current conditions, and Vargo and Lusch (2004) introduce a new dominant logic that is different from the goods- dominant logic. Dominant-logic focuses on the interaction between producers, consumers, and partners in the bidding network and the creation of value as parties who co-create through the process of collaboration. This logic is known as Service-Dominant logic.

Service-Dominant logic theory arises because of the impetus of the initial goal to do something for and with other parties better known as customer centric and customer responsive. In this logic, services are defined as the application of competencies through actions, processes and performance that are beneficial to other entities and the entities themselves. This can increase the company's strength to satisfy consumer needs and achieve organizational and social goals. In this case the company can be said to have the power to compete through services. And competition through services is more than adding value to the product. Effective competition through services must be carried out with the views and approaches of all parties in the organization aimed at providing satisfaction to consumers (Lusch et al., 2007).

This paper aims to explain the evolution of perception of marketing that occurs from goodsdominant logic to service-dominant logic, why service-dominant logic is chosen to overcome problems that occur, how service-dominant logic can be a conceptual basis for service science, and how critical elements in service-dominant logic can be competitive forces.

\section{Literature Review}

\subsection{Changes in Perspective in View of Marketing Activities}

Goods Orientation versus Service Orientation According to Vargo and Lusch (2004), showing the era before 1960, marketing activities were seen as a process of transferring ownership of goods and their physical distribution from sellers to consumers (Savitt, 1990); where it is seen as an application of goods movement (Shaw 1912). In the old view called the traditional / conventional view, marketing activities only focus on operand resources or goods as an exchange unit to be sold. Experts explain in a variety of literatures understanding marketing that rarely discusses the intangible products or services, and when discussing the role of services, the role of services is only explained in addition to the production and marketing of goods.

A series of continuous economic and social processes that focus on operant resources or the 
exchange of goods with the value of money from producers to consumers, are understanding of marketing, this theory states the view of Good-Dominant Logic, which is considered by Vargo and Lusch (2004) is less than perfect, because according to this theory marketing activities only have a view or will be cantered on goods (the goods-cantered view), so it can be explained that the essence of Good-Dominant Logic theory is as follows:

a) Making and distributing items that can be sold is the goal of economic activity

b) When goods are to be sold, they must have benefits and value during the production and distribution process and must be able to offer superior value compared to what is offered by competitors

c) Companies must set decision variables at a certain level that can maximize profits from sales of output

d) To maximize efficiency and control production, goods must be standardized and produced far from the market.

e) Goods can be stored until when needed and then given to consumers.

\subsection{Understanding Service-Dominant Logic Theory}

Lusch and Vargo, (2004) say that Service-Dominant logic theory provides the view that marketing activities will be centered on services (service centered view), which means that marketing activities are a series of continuous economic and social processes that focus on resources operands or transactions or exchanges between goods sold by producers / sellers to buyers / consumers, where the company as a producer / seller is trying to create a better value offer compared to its competitors And because the company tries always to do something better to serve its customers and improve financial performance, a service-centered view of perceiving marketing as an ongoing learning process.

According to Lusch and Vargo, (2004) argued that the Service-Dominant logic theory centered on services that can be stated in the marketing concept is as follows:

a) Introduce or develop key competencies, basic knowledge and expertise over economic entities that represent potential competitive advantages.

b) Identifying other entities, in this case are potential customers who can benefit from being linked to these key competencies.

c) Strengthening relationships that involve consumers in developing customized value offers and competing to meet certain needs.

d) Measure market feedback by analysing financial performance derived from exchanges to learn how to improve company offerings to consumers and improve company performance.

According to Lusch and Vargo, a service-centred view is based on 3 and is consistent with resource advantage theory (Conner and Prahalad 1996; Hunt 2000; Srivastava, Fahey, and Christensen 2001) and core competency theory (core competency theory) ( Day 1994; Prahalad and Hamel 1990) (Lusch and Vargo, 2004). In the theory of resource excellence, resources are corporate entities both tangible and intangible that can produce bids on the market effectively and efficiently and have value for several market segments (Hunt, 2000). So in this case the type of resources can be either operand resources or operant resources. Operand resources are static physical resources, such as machinery and raw materials. Whereas operant resources are resources that are dynamic like humans, related to organizational skills and knowledge, related to supervision, routine, and organizational culture; information, related to knowledge of market segments, technology, and competitors; and relations, related to relationships with competitors, suppliers, and consumers (Day et al, 2004). It was said that a service-cantered view was based and consistent with the theory of resource excellence because it was introduced and developed 
the main competencies, basic knowledge, and expertise of economic entities that represented potential competitive advantages. In addition, a service-centred view also bases and is consistent with the theory of core competencies because of that view the development of core competencies, basic knowledge, and expertise on economic entities that represent potential competitive advantages. According to Hamel and Prahalad (1994), the main competency is not a physical asset but rather an intangible process; Main competencies are a set of expertise and technology that are often routine, unspoken, ambiguous, or special actions or operations. Whereas Hunt (2000) states that main competencies are high-order resources because they are a set of basic resources. According to Teece and Pisano (1994) the competitive advantage of a company comes from dynamic capabilities that are rooted in routine operations that are highperformance within the company, which are inherent to the company's processes and are conditioned from the company's history. And according to Hamel and Prahalad competition in competence or competitive advantage resulting from competence contributes to the perception of consumer value (in Lusch and Vargo, 2004).

A service-centred view of marketing is customer centric and market driven. This means more than being oriented towards consumers and shows the existence of collaboration and learning from consumers that aims to be able to adapt to these consumers and their needs. In servicedominant logic, values are determined and created by consumers and not only attached to goods (output). Outcome is not something that is maximized but is something that is learned from how companies better serve consumers and improve performance. Therefore the service- centered model is appropriate when used in market-oriented and corporate learning processes (Lusch and Vargo, 2004)

\section{Conceptual Framework}

The pandemic condition due to Covid-19 now there is a change in the concept of economic transactions, which used to only sell products and without thinking about how the buying and selling process can reach consumers well so as to satisfy their consumers, in the hope that consumers will become loyal, where there are three forms of consumer loyalty, namely (1) making a repurchase (2) recommending to others (3) making what is felt to be a lesson.

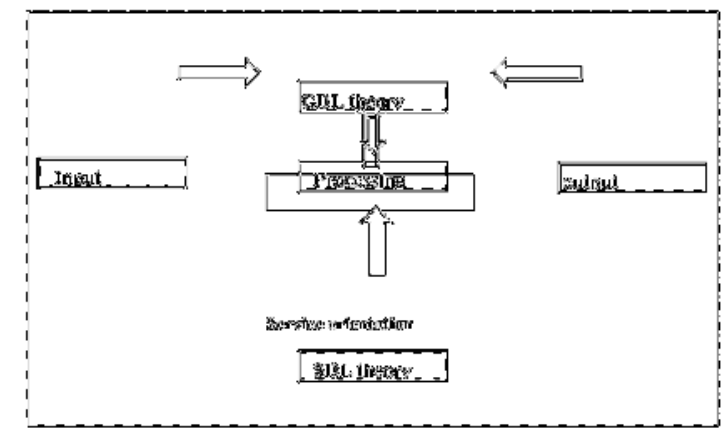

\section{Research Methods}


This research method is a part of science that studies how work procedures look for truth, where in the type of research this paper is qualitative that departs from field data and uses existing theories as supporters, then the results will bring up the theory of the data, with steps: The steps used are (1) Positioning Theory (2) collecting data and interpreting it and validating data (3) Finding Novelty or finding new discoveries so that they can contribute both to science and to life.

\section{Results and Discussion}

\subsection{The process of changing economic transactions from the theory of Dominant Logic to Service Dominant Logic}

Lusch and Vargo (2006a) proposed a change of perspective in marketing at the Otago forum in 2005 which was presented in tabular form (see Table). The table shows how the concept of dominant logic in marketing undergoes a transition from goods-dominant logics to servicedominant logic. The first column is goods-dominant logics, the term output-based which was widely used around the 1800s and dominated until 1980. In goods-dominant logic output tangible and discrete transactions are central issues. Goods-Dominant logic focuses on the efficiency of the production of tangible goods that have value through the exchange of forms during the manufacturing process. This suggests standardization, keeping production away from the market and consumer interference, and storing output until it is sold. In this logic distribution and marketing have a role to add value by producing the benefits of place, time, and ownership. And efficiency is directed at design and not at market efficiency as found in service-dominant logic (Lusch et al., 2008)

Around 1980 thought began to experience a transition which was a manifestation in terms of service marketing, relationship marketing, views on exchange and competition based on resources and so on. Although in some ways it has led to services, the provision of benefits and the delivery of value to consumers, people still have a perspective that leads to goods-dominant logic (Vargo and Lusch, 2004). After 1980, new marketing was free from the belief in goodsdominant logic and was familiar with the term service-dominant logic contained in column 3 , where intangible goods, the exchange process, and customer relations were the central issues. But the bond over goods- dominant logic is still strong and people must try to accept the term service-dominant logic.

In accordance with what was stated by Lusch and Vargo (2004) that the view of servicecentred (1) is not limited as is the case with traditional concepts that often perceive servicesas residuals, (2) not something offered to get a product (value-added service), (3) not something that is classified as a service industry. In service-dominant logic, service is the application of special competencies of knowledge and skills through actions, processes and performance that are beneficial to other entities and entities. So in this case, service-dominant logic represents a philosophy re-orientation that can be applied to all marketing offers including tangible output (goods). And marketing that is customer-centric, market-driven, has a service-centered view should (1) focus on specific knowledge and skills as operant resources that provide competitive advantage, (2) strive to maximize consumer involvement in developing offerings, (3) aims to be the main organizational philosophy that leads in starting and coordinating market-driven perspectives to all major competencies (Day, 2004).

Service-dominant logic views consumers as operant resources, that is resources that are able to act with other resources, are partners who can be invited to collaborate with companies and 
colleagues in the bidding network to create value and promote the philosophy of 'marketing with. In Service-dominant logic, knowledge and ability to collaborate are the key drivers for companies to be more successful in competition. Lusch et al. (2007).

Table 1. Dominant Logic

\begin{tabular}{lll}
\hline $\begin{array}{l}\text { Goods-Dominant Logic } \\
\text { Concepts }\end{array}$ & Transitional Concepts & $\begin{array}{l}\text { Service-Dominant } \\
\text { Logic Concept }\end{array}$ \\
\hline Goods & Services & Service \\
Products & Offerings & Experiences \\
Feature/attribute & Benefit & Solution \\
Value-added & Co-production & Co-creation of Value \\
Profit maximization & Financial engineering & Financial feedback/learning \\
Price & Value Delivery & Value proposition \\
Equilibrium systems & Dynamic systems & Complex adapative systems \\
Supply chain & Value-chain & Value Creation \\
& & Network/constellation \\
Promotion & Integrated marketing & Dialogue \\
& communication & \\
To market & Market to & Market with \\
Product orientation & Market orientation & Service orientation \\
\hline
\end{tabular}

\subsection{The Importance of Service-Dominant Logic in the Current Period}

On various occasions it is often questioned whether 'service' is the best character of the new dominant logic? Much research is motivated to believe that services win the debate between goods and services. Or in other words, services are better than products. Vargo and Lusch (2004) state that a mistake in the debate is due to the different 'service' treatments, namely as a special type of intangible product that is not contained in the goods. This is not consistent with servicedominant logic.

The use of 'services' in the singular in service-dominant logic shows the process of doing something for someone rather than 'services' which states the unit of output as explained in the goods-dominant logic. The debate between goods and services is related to the difference between goods and services, that goods are a complement used in the provision of services. In servicedominant logic, service is a general designation of exchange and refers to goods.

Some argue that the basis of service-dominant logic in new definitions of services is inconsistent with traditional definitions. In this case the service is defined as the application of competence which includes skills and knowledge through actions, processes and performance that benefit other entities as well as the entity itself. This is a new definition and is considered wrong (Lusch and Vargo, 2006; Vargo and Lusch, 2008). However, this definition is consistent with the definition contained in the literature revealed by Gronroos (2000) that services are a process that consists of a series of activities that use a number of different resources in their direct interactions with consumers in relation to finding solutions to consumer problems (in Lusch and Vargo, 2006; Vargo and Lusch, 2008). Based on this it can be said that the service is the use of one's resources that are profitable for other entities. And there are no other words that are more appropriate to describe this than service.

Vargo and Lusch (2008) also believe that service is something simple but is a very strong 
construct and has multiple aspects. This is the right goal, not only to characterize the emergence and gathering of marketing thoughts, but also to accurately inform and motivate relevant research, practice and public policy. In addition, the idea that services are the basic concept of exchange and marketing has strong and important normative implications that bring different objectives and processes closer to marketing activities and the company as a whole to provide services for interested parties including consumers, shareholders, and the employee. This leads directly to the normative view of investment in people (operant resources), long- term relationships, quality service flows, and only a few leads directly to symmetry, transparency, ethical approaches to exchange, and sustainability. This direction has advantages for both companies and the public that are not found in goods-dominant logic. That is what answers the question "why service-dominant logic?". In addition, service-dominant logic is also the right and strong thing to inform and stimulate the evolution of marketing thinking and practice.

\subsection{The purpose in Service-Dominant Logic}

As explained in Evolving to a New Dominant Logic for Marketing by Vargo and Lusch (2004) based on what is explained by Fredric Bastiat (1860) related to his historical writings that the essence of economic activity is the exchange of services for services and corporate objectives is to provide a mechanism for the occurrence exchange services to improve the standard of living of consumers or provide services needed by consumers better. Or in other words the company's goal is not to make and sell output units but rather to provide services that are 'customized' for consumers and other organizations.

Modern companies are given the power to operate in society as long as they provide something fair for exchanges. To achieve this, the parties concerned must be satisfied both from what is done / produced and for what is consumed. If the welfare of the company is realized but does not provide something fair for its customers, then the company will lose its right to operate. Service-dominant logic is prescriptive in terms of ethical issues that are of little concern in goods-dominant logic. We believe that this is important because the market operates without normative ethical guidelines will produce something imperfect and externalities that can be avoided by the existence of service-dominant logic.

\subsection{Normative Guidance in Service-Dominant Logic}

According to Lusch and Vargo (2006b), there are several normative guidelines offered in service-dominant logic that companies can use to act, namely:

a) The company should be transparent and make all information symmetrical. Because consumers are the collaborating parties, nothing else is needed for the success of the collaboration other than honesty.

b) Companies should strive to build relationships with consumers and use a long-term perspective. And then the company also should always be careful of consumer interests and protect consumers for the long term.

c) The company should see the goods as a sign of operant resources that become intermediary products used by other operant resources as a complement in the process of value creation. In this case the company should focus on the flow of service sales.

d) Companies should support and invest in the development of special skills and knowledge that are sources of economic growth.

Many macro marketing focuses on public policy and is directed at marketing oversight whether related to prices, advertising, products (product liability and safety), promotional 
tactics, or other things done by companies related to marketing. However, as explained (Vargo and Lusch, 2004) that even though the company is oriented transactional and not relational, the company must still pay attention to the welfare of its consumers. Exchange is a relational form even though the company chooses to be transactional. And we cannot say that all companies adopt Service-Dominant logic. Although they do not adopt service-dominant logic, servicedominant logic provides normative guidance on how a company should act (Lusch and Vargo, 2006b).

\subsection{Service-Dominant Logic as a Conceptual Basis for Service Knowledge}

Maglio and Spohrer said that the service system is a configuration of value co-creation between people, technology, value offerings related to internal and external service systems, and information sharing that includes language, law, size, and method. And service science is the study of service systems that aim to create a basis for systematic service innovation. Service science combines organizational and people understanding with an understanding of business and technology to categorize and explain the different types of service systems that exist and how they interact and develop to create value. It aims to apply scientific understanding to develop the ability to design, improve and scale service systems. And service-dominant logic provides correct perspectives and assumptions to develop service system theory, its configuration and interaction models. In short, it can be said that service-dominant logic becomes the philosophical foundation for service science and service systems as the basis of theoretical constructs (Maglio and Spohrer, 2007).

\subsection{Novelty: Competitive Advantage through Service-Dominant Logic}

The process and orientation of service-dominant logic resources offer a perspective for the conceptual basis of the science of service marketing that can produce competitive power for companies. The competitive advantage in service-dominant logic can be understood through critical elements that distinguish between service-dominant logic and goods-dominant logic as follows.

\section{a) Company Resources}

Goods-dominant logic isoriented towards operand resources, that is, resources that are used that are static and require other resources that are more dynamic to make it useful. Most of the natural resources are operand resources. Companies that focus on operand resourcesare usually (1) manufactures that exchange goods, (2) consumers are seen as segmented, penetrated, distributed, and promoted operand resources, assets are conceptualized achieved from tangible resources by adding additional resources value with certain activities, traditionally, exchange is seen as a method to maximize profits by using more goods.

Service-dominant logic focuses on operant resources, that is, resources that are capable of acting with operand resources or even other operant resources to create value. And competition is how companies can apply operant resources to meet consumers more than can be done by other companies (Lusch et al., 2007). As explained earlier that operant resources are resources that are capable of acting with operand resources and in this case are closely related to human resources owned by the company. Human resources are very personal and unique that can produce something unique too. That is what can be used by companies as a competitive force. And in service-dominant logic the creation of competitive advantage occurs throughout the provision of these services. That is because throughout the process of providing services, 
consumers can judge whether the company is superior compared to other companies in providing the services needed.

\section{b) Competence and Collaboration}

In goods-dominant logic, value creation is associated with the acquisition of resources, the majority of which are operand resources. Whereas in service-dominant logic, value creation occurs when potential resources turn into certain benefits. These activities include aspects of resource creation, integrating resources, and maintaining the removal of resources.

Competency advantage is obtained from different competencies that are not owned by other companies. Competence is becoming increasingly specialized. The creation of different resources is done by creating and increasing the knowledge and competencies of members in the organization by sharing that knowledge and abilities among members of the organization. Integrating resources is a basic function of the entire service system which aims to create a service offering. And this integration does not only occur between members of the organization, but also to parties outside the organization (for example between companies, households, and government). And the general principle is that existing resources do not have intrinsic value if they are not integrated with other resources. Whereas eliminating resources occurs because of obstacles from certain resources to other resources. Therefore, the removal of certain resources continues before potential resources are used. This does not only occur within the company but can also be for potential customers or suppliers. Appropriate collaboration not only produces more value for consumers but can also reduce costs with resource efficiency.

\section{c) Process of Delivering Services and Experiences}

The goods-dominant logic view has a main focus as the production of output to be sold to consumers which traditionally outputs are tangible, intangible, or a combination of both. And companies will try to standardize these outputs even for services (intangible goods) even because of their manufacturing nature. Production efficiency can only be achieved by specialization.

The focus of service-dominant logic on the interaction between companies and consumers and the process of creating experience is one form of transaction that allows value creation that can be applied to all social and economic actors. And the significance of the interaction is not on the transfer of ownership of output (as in goods-dominant logic) but on the interaction itself. Experience during interaction will affect the assessment of consumers and is the value given to consumers. This is a fundamental learning process. In the process, it can be learned what the wants and needs of consumers are and try to offer value that is beneficial to consumers. Competitive advantage can be achieved with innovation. And innovation can be achieved through the creation of these experiences. The focus is on effectiveness in responding to consumers and not on efficiency in producing services.

\section{d) Supply and Value Creation}

As discussed earlier, the orientation of the view on goods-dominant logic aims that companies produce and sell output. In this case the value is created by the company and given to consumers. If the company wants to increase profits, the company needs to produce and sell more units of output.

In the service-dominant logic view, consumers are not only as buyers of output created by 
companies, but as input integrators that are provided by companies with other resources to create value. Because consumers integrate existing resources to create value, service-dominant logic recognizes that companies cannot create value but only offer value. How companies can invite and direct consumers to jointly create value in accordance with what is expected by consumers can be competitive for the company.

Value creation does not only occur between companies and consumers but also members of the service system network. Disbursement of information changes the location and nature of work as well as linkages with resources, and with the increase in information disbursement capabilities also increases the opportunity to concentrate on certain competencies and take from outside the complementary competencies needed. This resulted in the need to re-conceptualize the existing supply chain into a service system network.

\section{e) Communication}

In goods-dominant logic, consumers are considered as operand resources that are subject to certain actions such as segmented, targeted, and penetrated through promotion. Promotion here is only one side and tends to influence consumers to buy company output. In service-dominant logic, consumers as operant resources can create value. This shows a two-way dialogue between consumers and companies that can build trust, shared learning, and mutual adaptation. It aims to develop the understanding of each participant, and the interaction builds appropriate conditions for mutual listening and learning. The ability to communicate with consumers must always be evaluated and improved so that the company can still understand the needs and desires of consumers.

\section{f) Collaborative Marketing}

In the view of service-dominant logic that views consumers as operant resources, consumers are considered partners who can be invited to collaborate in creating value or as endogenous that influence the value to be created. This shows marketing with an approach (marketing with approach). Whereas in the view of goods-dominant logic, marketing is to treat consumers as exogenous or influenced. The essence of this business philosophy is the adoption of the collaboration process and the collaboration method as a general philosophy for business. Some of these thoughts are reflected in closer working relationships. This is not only faced by service systems that serve the market, but also other private and public service systems.

\section{Conclusion}

As time changes, the focus of attention changes from tangible things to intangible things, such as expertise, information, and knowledge, as well as interactivity and relational. The orientation also changes from producer to consumer, as well as the focus of exchange which was only on the sale of output into the exchange process itself, namely transactional to relational, which generates loyalty between producers and consumers. Science moves from focusing on something mechanical to something dynamic that requires system adaptation which is basically consumer behavior is something that is dynamic.

The conceptual basis of service science based on service-dominant logic has the potential to become a platform for organizational views as a service system. Service-dominant logic is believed to provide a framework for theorizing, confirming, and improving the theoretical basis 
of service science. And to have evolutionary potential, both service-dominant logic and service science must be co-authorized by other parties.

The change from goods-dominant logic that focuses on the exchange of goods to servicedominant logic that is oriented toward exchanging services directs the need for companies to think about resources, value creation, and competition. And competition is about creating excellence through resources or adding value to these resources. In service-dominant logic operant resources are the main thing and can be used as competitive forces because of their unique nature. And the value offered to consumers comes from the ability to act that utilizes the many resources to be useful for the parties concerned. In order to fulfil their needs and desires appropriately, consumers are involved in creating that value.

\section{References}

[1] Harrington, Robert J. et al. 2019. "From Goods-Service Logic to a Memory-Dominant Logic: Business Logic Evolution and Application in Hospitality." International Journal of Hospitality Management 76(November 2017): 252-60. https://doi.org/10.1016/j.ijhm.2018.05.014.

[2] Lusch, Robert F., Stephen L. Vargo, and Matthew O'Brien. 2007. "Competing through Service: Insights from Service-Dominant Logic.” Journal of Retailing 83(1): 5-18.

[3] Rothan, Hussin A., and Siddappa N. Byrareddy. 2020. "The Epidemiology and Pathogenesis of Coronavirus Disease (COVID-19) Outbreak." Journal of Autoimmunity.

[4] Day, George S., Deighton \& Narayandas, Gummesson, E., Hunt, Shelby D., Prahalad, C.K., Rust, Roland T., Shugan, Steven M. (2004), "Invited Commentaries on 'Evolving to a New Dominant Logic for Marketing”", Journal of Marketing, Vol. 68 (Januari): 18-27

[5] Lusch, R.F. and S.L. Vargo (2006a), "Service-Dominant Logic: Reaction, Reflections, and Refinements", Marketing Theory, Vol. 6(3): 281-288

[6] Lusch, R.F. and S.L.Vargo (2006b), Service-Dominant Logic as a Foundation for a General Theory in The Service Dominant-Logic of Marketing: Dialog, Debate, and Direction, M.E. Sharpe, Armonk, New York: pp. 406- 420,3and

[7] G.Wessel (2008), "Toward a Conceptual Foundation for Service Science: Contribution from Service- Dominant Logic", IBM System Journal, Vol. 47 (1): 5-14, and Matthew

[8] Lusch, R.F. and S.L. Vargo (2006a), "Service-Dominant Logic: Reaction, Reflections, and Refinements", Marketing Theory, Vol. 6(3): 281-288

[9] Lusch, R.F. and S.L.Vargo (2006b), Service-Dominant Logic as a Foundation for a General Theory in The Service Dominant-Logic of Marketing: Dialog, Debate, and Direction, M.E. Sharpe, Armonk, New York: pp. 406- 420

[10] Maglio, P.P. and Jim Spohrer (2007), "Fundamental of Service Science", Journal of the Academy Marketing Science, Vol. 36(July): 18-20

[11] Vargo, S.L. and R.L.Lusch (2004), "Evolving to a New Dominant Logic for Marketing", Journal of Marketing, Vol.68 (January): 1-17

[12] Vargo, S.L. and R.L.Lusch (2008), "Why 'Service'?”, Journal of the Academy Marketing Science, Vol 36(August):

[13] O'Brien (2007), "Competing through Service: Insight from Service-Dominant Logic," Journal of Retailing, Vol. 83, No.1, pp. 5-18

[14] Maglio, P.P. and Jim Spohrer (2007), "Fundamental of Service Science", Journal of the Academy Marketing Science, Vol. 36(July): 18-20

[15] Vargo, S.L. and R.L.Lusch (2004), "Evolving to a New Dominant Logic for Marketing", Journal of Marketing, Vol.68 (Januari): 1-17

[16] Vargo, S.L. and R.L.Lusch (2008), “Why 'Service'?”, Journal of the Academy Marketing Science, Vol 36(August):25-38 